\title{
CROSSING BORDERS ON THE BALKAN ROUTE: REPRESENTATION OF MIGRATION IN ONLINE NEWS
}

\author{
Svetlana Nedelcheva*
}

\begin{abstract}
This research studies the headlines representing migrants along the Balkan route in Bulgarian online news during the "migrant crisis" of 2015/2016, as well as the pictorial images that immediately follow the headlines. It compares the verbal and the visual representation of migrants and applies both critical discourse analysis and multimodal analysis. The study uses the term 'text' in a wider sense including both the verbal text and the pictorial display of migrants' social activities.

The headlines develop two contradicting images of the migrants which are also reflected in the pictures. One of them is the image of poor and distressed people running away from the war in their home country. Europe for them is the Promised Land and they are presented with sympathy and compassion. The other image of the migrants is that of a natural disaster which cannot be stopped by country borders and threatens the stability on the continent.
\end{abstract}

Key words: migrants, headlines, multimodality, conceptual metaphors, visual representation

\section{Introduction}

Since August 2015 till March 2016 approximately half a million people have migrated to Europe via the Western Balkans, the vast majority seeking asylum in the countries across the European Union (EU). Building on news pieces published by online TV news in the same period, this study seeks to provide an overview of countries' disposition towards migrants and to identify the influence of changing European policies towards migration and the people who have travelled to Europe through the Western Balkans by focusing on the means of expression used in the article headlines.

The vast flow of migrants, which caused the "migrant crisis" in Europe, has originated from countries affected by conflicts. Syrians still make up the majority of the newcomers, although their overall number has proportionally decreased in comparison to previous years. Instead, an increasing number of

* Assoc. Prof. PhD at the Department of English Studies, Shumen University, Shumen, Bulgaria, e-mail: s.nedelcheva@shu.bg. 
arrivals from people of other nationalities has been registered, including such refugee-producing countries as Iraq, Afghanistan, etc.

According to the statistical data collected by $\mathrm{REACH}^{*}$, mainly young adults have arrived to Europe, males outnumbering females. People mostly travelled with close family members from the same area of origin, with an increasing proportion of families noted in Afghan, Iraqi and Syrian groups over the observed period.

Among the migrants many are educated and experienced professionals. However, the ratio of vulnerable migrants has increased during the "migrant crisis", with rising proportions of uneducated people with no reliance on stable employment in their home land. REACH reports $55 \%$ of adults in the assessed groups that had completed at least primary or secondary education and $20 \%$ with experience of higher education. Apart from the Afghans all other nationalities claim having stable income (employment with labour contract, business ownership, etc.) or relying on both "stable" sources and "unstable" sources of income (e.g. daily or casual work). As reported by REACH, prior to leaving their areas of origin most had made a significant investment in order to ensure the journey financially, usually selling their property, spending savings, or taking out loans.

According to the Guardian**, at least 24,000 people have made the journey along the Balkans route until it was shut in early March, highlighting that migration continues despite the fact that several eastern and central European countries have constructed fences along their borders (Macedonia, Hungary, Austria). Although the closure of the humanitarian corridor from Greece to Germany decreased the migration numbers considerably, since 9 March 2016 24,790 people are estimated to have reached eastern Europe through Serbia, a key point on the two major migration routes (see Figure 1), according to the analysis of data provided by the UN refugee agency published in the Guardian (2016). Many have entered EU through Bulgaria instead of hiring boats in Turkey to take them to the Greek islands, where new arrivals have been detained after landing. Those confined to Greek migrant camps sometimes paid smugglers to take them to Macedonia's border. 21,231 of them are reported as having reached Austria, the last stop on the way to Germany. This is less than 3 percent of the total during the period studied in this paper (August 2015 - March 2016), but

\footnotetext{
* http://www.reach-initiative.org/reach/about-reach REACH is a joint initiative of IMPACT, its sister-organization ACTED, and the United Nations Operational Satellite Applications Programme (UNOSAT). REACH was created in 2010 to facilitate the development of information tools and products that enhance the humanitarian community's decision-making and planning capacity.

** https://www.theguardian.com/world/2016/aug/30/tens-of-thousands-migrate-throughbalkans-since-route-declared-shut
} 
it exceeds the annual total for 2013, and is more than three times greater than 2012's annual figure (see Figure 2).

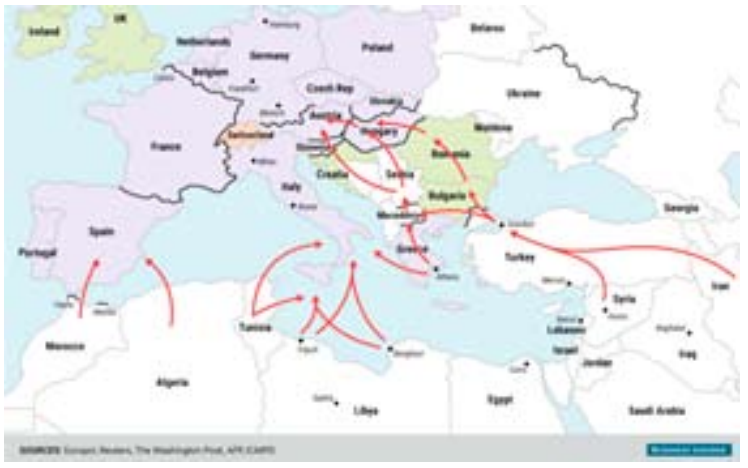

Figure 1. The Balkan route*

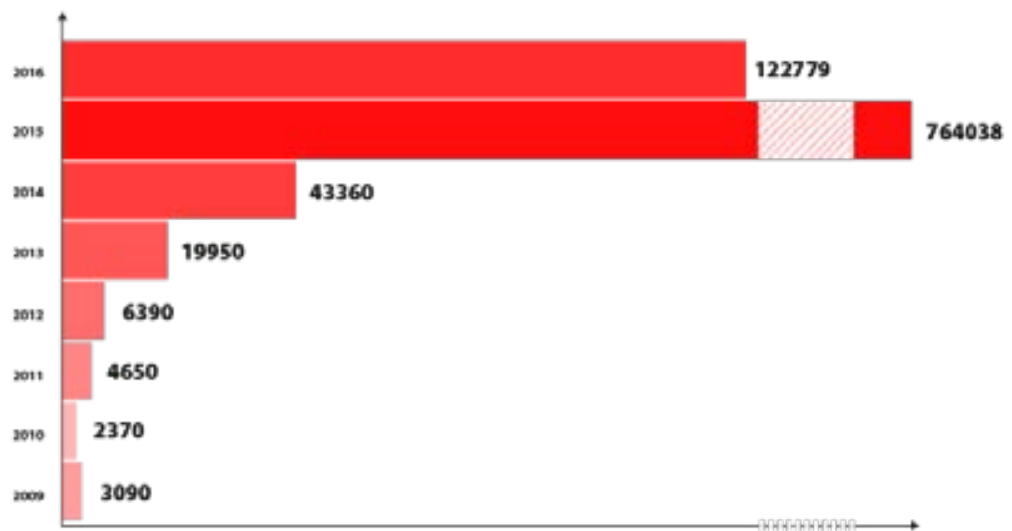

Figure 2. Illegal border crossings on the Western Balkans route in numbers ${ }^{* *}$

\section{Methodology}

This study focuses on the expressive devices used in the headlines of online news presenting migrants on their way from Turkey or Greece to western Europe and how the pictorial images accompanying them help them convey the message. For achieving these objectives we count on two main methods of analysis: critical discourse analysis and multimodal analysis.

We have chosen critical discourse analysis because it studies the ways in which language is used in text and because it involves real texts not ones that are

\footnotetext{
* http://www.businessinsider.com/map-refugees-europe-migrants-2016-2

** http://frontex.europa.eu/trends-and-routes/western-balkan-route/
} 
invented or artificial. It is defined as analyzing language "beyond the sentence" and looks not only at what is said on the surface level but considers the contiguous social and historical contexts (LSA 2016). Critical discourse analysis provides a way of approaching a problem and revealing the hidden motivation behind a text. It allows the researcher to take a higher stance and gain a comprehensive view of the problem.

The multimodal analysis (van Leuween 2008; Kress, van Leeuwen, 1996/2006; Jewitt, Bezemer, O'Halloran 2016) interprets "text" in a broad sense and includes all available semiotic resources, e.g. layout, photographs, etc. However, according to Kress and van Leeuwen (1996: 2), this does not mean that visual structures are like linguistic structures. "The relation is much more general. Visual structures realize meanings as linguistic structures do, and thereby point to different interpretations of experience and different forms of social interaction."

We also use elements of quantitative analysis to summarize the results of empirical data. The numbers provided do not ensue from a specific statistical method, rather they exhibit the frequency of the phenomena under investigation in the corpus.

Previous research into newspaper headlines has raised the question of whether the style of Bulgarian news headlines has changed over the years; studies have not however involved headlines from a wide enough range of data to allow for conclusions to be drawn. According to Pernishka (1999: 131), "this style (considering the provocative, rude, even brutal style) does not represent the "freedom of speech," but only shows authors or editors ... who do not distinguish the original, witty, glamorous means of expression - a weapon of good journalism, of the shameful, low and even vulgar." Other studies analyse the functions of headlines: Nikolova defines several functions of headlines: firstly, it is a semantic condensate of the information essence of the text; secondly, the title has an intentional nature, because it fixes the most important, the most attractive; thirdly, the title usually carries in its meaning additional connotations, metaphorical, emotionally-expressive and nationally-cultural, which make it up-to-date for the reader's audience (Nikolova 2003: 257). Zambova (2000: 57) argues that the functional and manipulative role of news headlines has grown considerably. It could mislead the reader to read the material only to find out it has nothing to do with the text itself. It may be more interesting than the text, or it may not inspire a desire to read. It may well be enough to replace reading the text.

However, this research concentrates mainly on the linguistic features which are typical of them. It further suggests that headlines are particularly revealing of the social and cultural specificities of the people presented in the news pieces and the attitudes circulating in the society at the given period of time. This research 
addresses: 1. The structure and syntax of news headlines (using examples from our corpus). 2. The characteristic linguistic features of news headlines. 3. Multimodal analysis considering both headlines and accompanying images.

The source of the corpus of the present study is bTV online news (btvnovinite. $\mathrm{bg}$ ) as it presented the largest number of news pieces found with the key word "имигрант" (immigrant) when compared to other online media, namely 24chasa.bg, Novini.bg, nova.bg. The corpus of the study comprises all 334 pieces of news discussing migrants over a period of 7 months (15 August 2015 - 15 March 2016) together with the images and video clips. The verbal parts are accompanied by one to three images and / or video clips. We, however, are going to analyze only the headline and the image immediately following it. If there is a video following it we won't analyze the whole video but only the initial still image of the clip.

\section{Structure and syntax of news headlines}

Headlines are read by an audience even wider than that who reads the articles, since all those who open the news website will glance, if only fleetingly, at the headlines. Moreover their effect is even more extensive, since headlines are often glimpsed on other people's computers, tablets, phones, etc. Unlike headlines printed in newspapers where front page headlines are particularly eye-catching, online headlines are not arranged in pages which gives the casual observer the opportunity to treat them with equal importance and they are given prominence by the frequency of publishing per day on a particular issue, e.g. nine news on migrants were published on 2 September 2015; another nine pieces on 4 September 2015; nine on 5 September 2015; ten on 6 September 2015; ten on 16 October 2015, etc.

Headlines are a special form of short texts. News headlines inform and entice in just a few words. The analysis of verbal phrases in our corpus in terms of complexity indicates that the simple structure of verbal phrases prevails. There are mostly simple clauses consisting of one independent clause, containing a subject and a verb, additionally they are accompanied by objects and adverbials, for instance:

(1) 3650 бежанци са пристигнали във Виена (1/9/15) ‘3,650 refugees have arrived in Vienna' $\rightarrow$ Subject (3 650 бежанци) + verb (са пристигнали) + adverbial (във Виена)

(2) Плевнелиев се скара на гърци и хървати заради мигрантите $(21 / 9 / 15)$ 'Plevneliev scolded Greeks and Croats for the migrants' $\rightarrow$ Subject (Плевнелиев) + verb (се скара) + object (на гърци и хървати) + adverbial (заради мигрантите) 
(3) БСП иска свикване на съвет по сигурността при президента заради бежанците (1/9/15) 'Bulgarian Socialist party wants to summon a security council at the presidency for the refugees' $\rightarrow$ Subject (БСП) + verb (иска) + object (свикване на съвет по сигурността) + adverbial (при президента) + adverbial (заради бежанците)

Although compound and complex sentences also appear they are less frequent:

(4) Бежанската криза в Европа се задълбочава, но европейците откликват с помощ (2/9/15) 'The refugee crisis in Europe is deepening but Europeans offer help'

(5) Великобритания ще отдели до 12 млрд. лири, за да подпомогне сирийските бежанци (2/9/15) 'Britain will allocate up to 12 billion pounds to help Syrian refugees'

To achieve brevity journalists sometimes merge two sentences into one: (6) Унгарски политик преряза оградата, полицията го прибра (1/9/15) 'А Hungarian politician cut the fence, police arrested him'

(7) Дейвид Камерън отстьпи, Великобритания ще приема още бежанци (4/9/15) 'David Cameron gave in, Britain will accept more refugees.' Instead of having two separate sentences the authors try to convey maximum information by connecting the two clauses.

The preferred sentence type in the headlines of the corpus is the declarative due to its ability to inform, present statistical data and describe the current situation, political, economic, etc. Ten of the examples are expressed with questions instead of statements. Some of them use a question word, e.g. (8) Как е организиран трафикът на имигранти? (5/9/15) 'How is the immigrant traffic organized?', while the others are yes-no questions, e.g. (9) Подкрепяте ли бежанците да бъдат разпределени в Европа по квоти? (9/9/15) 'Do you support refugees to be distributed in Europe by quota? These questions suggest what answers can be found in the material. Some of them sound like suppositions, others as rhetorical questions. The goal is for the reader to show interest and desire to read the article, to find the answer to this question. In these titles there is something unexpressed, implicit and the readers have the impression that the question is also addressed to them.

Citations are a widely used technique in constructing news headlines (40 instances found in the corpus). The journalist uses the originality of the expression of a popular person, an institution, a party. The quote attaches authenticity to the event. Always the most interesting remark is extracted from the text. At the same time, if it does not conform to norms, principles, rules, then the responsibility does not reside in the author of the publication. 
Citations in our corpus belong primarily to local or foreign politicians, e.g. (10) Митов: Европа трябва да започне да врыща имигранти (4/12/15) 'Mitov: Europe has to start sending back immigrants'; (11) Меркел: Решаването на проблема с бежанците е национална задача на Германия (5/9/15) 'Merkel: Resolving the problem with refugees is a national task for Germany.' Sometimes the name of the politician is not mentioned explicitly but is inferred from his/her position in the country, e.g. (12) Чешкият премиер: Готови сме да защитим границите на балканските страни при мигрантската криза (14/2/16) 'Czech Prime Minister: We are ready to protect the borders of the Balkan countries in case of migration crisis'. Seldom citations are extracted from other newspapers or magazines, e.g. (13) "Политико": България е “ад” за нелегалните имигранти (29/2/16) 'Politiko: Bulgaria is a "hell" for illegal immigrants' or the name of the country is used to stand for the opinion of its government, e.g. (14) Гърция: Имигрантската вълна може да ни заличи като държава (23/8/15) 'Greece: the Immigrant wave may wipe us out as a country'. Citations in headlines follow the same structural pattern: 1 . The name of the person/country/newspaper cited, followed by a colon (there is no verb in this clause). 2. Direct speech, which is not indicated by quotation marks. A variation of this structure is the following: (15) Ако пуснем всички мигранти, това ще унищожи Европа, убеден е Орбан (6/9/15) 'If we accept all the migrants, it will destroy Europe, Orban is convinced'. In this structure the direct speech comes first and it is related asyndetically to another clause which introduces the name of the speaker.

The corpus showed only two headlines containing verbless clauses, e.g. (16) Пьтят на нелегалните имигранти през Европа (7/9/15) 'The way of the illegal immigrants through Europe'; (17) Пореден случай на заловени нелегални мигранти (7/12/15) 'Another case of illegal migrants caught'. This finding can be explained with the difference between tabloid headlines and headlines in quality press. The former tend to be brief and short and rely more on sensation (Matthews and Brown 2012: 7), while the latter are mainly structured in full sentences as they aim to provide as much informativity as possible having in mind their conciseness.

\section{The characteristic linguistic features of news headlines}

Headlines set a particular perspective that helps orienting the readers in their interpretation of the consequent facts contained in the articles. As Abastado (1980: 149 cited by Salih Abu Joloud 2015) suggests "headlines encapsulate not only the content but the orientation, the perspective that the readers should bring to their understanding of the article." Successive headlines, especially in online news, as they follow each other sometimes more than ten times per day, structure a particular view point on the world by imposing on the information a hierarchy of importance. The corpus of the present study reveals a tendency 
to convey news from different parts of the world connected to the hot topic, e.g. (18) Унгария е готова с антиимигрантската ограда по границата (29/8/15) 'Hungary is ready with the anti-immigration fence along the border'; (19) Катер на Фронтекс откри задушил се млад мигрант на яхта край грьцки остров $(29 / 8 / 15)$ 'Frontex boat found a suffocated young migrant on a yacht near a Greek island'; (20) В Дрезден хиляди участваха в шествие в знак на солидарност с бежанците (30/8/15) 'In Dresden thousands participated in a procession to support refugees'; (21) Шведската крайна десница иска референдум за имиграцията (30/8/15) 'The Swedish right wing wants a referendum on immigration.' Four countries are mentioned in the other pieces of news on the same day (30/8/15): France, Germany, the United Kingdom and Syria.

On this particular day (30 August 2015) there is a line of Bulgarian news concerning an accident of fatal transportation of migrants by Bulgarian drivers, e.g. (22) Кунева: Трябва да ни е срам, че българи са били замесени в трафика на бежанци (30/8/15) 'Kuneva: We must be ashamed that Bulgarians were involved in the trafficking of refugees'; (23) Задържан е още един българин за трагедията с камиона ковчег в Австрия (30/8/15) 'One more Bulgarian was detained for the tragedy with the coffin truck in Austria'; (24) Още един българин арестуван, заради смъртта на 71 имигранти (30/8/15) 'Another Bulgarian arrested because of the deaths of 71 immigrants.' Repetition both synchronic (co-occurring headlines within one day ) and diachronic (repetition over time) 'chains' the facts and makes the reader develop certain expectations and establishes certain associations and interpretations. Thus anaphoric references relate headlines to previous events and situations, encouraging the readers to link events in ways which they might not have done otherwise. In our corpus we find that sometimes distant topics group articles together to the issue of migration.

Headlines are particularly informative in the field of cultural references. As titles are short and 'isolated' (without explanation or definition) they depend on the reader to recognise instantly the field, allusions, issues, cultural references necessary to identify the content of the articles. Thus they count on a supply of background knowledge, representations and models of reality that are considered to be widespread in the society if the headlines are expected to be understood. Common shorthand in headlines such as references to 'MB $\Phi$ ', 'International Monetary Fund' or 'БXК', 'Bulgarian Helsinki committee', presuppose not only a certain minimum of political and general knowledge, but also help to situate the Bulgarian readers within the national framework. The same refers to elliptical phrases such as (25) Външно предупреди за затруднения в движението в Австрия и Словакия (15/9/15) 'Foreign" alerted about traffic

* 'Foreign' here is a literal translation of 'външно'. 
difficulties in Austria and Slovakia.' Using just 'foreign' instead of Ministry of Foreign Affairs requires readers to share specific communal information.

Gallisson (1995 cited by Isani 2011) argues that such reworkings of linguistic and cultural forms constitute a 'conspiratorial wink' directed to the reader. They build and preserve a sense of shared knowledge and collective identity. More broadly, it is clear that this is applicable to all the cases in which cultural insights peculiar to a certain society must be activated to help understanding: successful decoding proves that the reader is an 'insider'. Because of their brevity headlines rely to a greater extent than the articles themselves on the reader supplying the missing cultural links.

The recognition by the reader of various metaphors and metonymies also depends on general and cultural knowledge. Metaphor is a very typical feature of headlines but generally it is not only confined to the headlines but also to the body of articles. The most common metaphor in the corpus of the present study is the WATER METAPHOR, displayed by a semantic chain of nouns and verbs*. Adjectives are limited and appear in collocations with particular nouns (discussed below).

\section{Nouns}

- вълна 'wave', e.g. (26) Бежанската вълна повлия и на местните избори (4/10/15) 'The refugee wave also affected the local elections'; (27) Имигрантската вълна ще покаже колко голямо е сърцето на Европа (9/9/15) 'The immigrant wave will show how big the heart of Europe is'; (28) Германия е готова да мобилизира 4000 военни в помощ за имигрантската вълна (11/9/15) 'Germany is ready to mobilize 4,000 troops to help with the immigration wave.'

- поток 'flow/ stream', e.g. (29) Нидал Алгафари: Русия, Турция и САЩ изпратиха потока бежанци, за да притиснат Европа (8/10/15) 'Nidal Algafari: Russia, Turkey and the United States sent the flow of refugees to press Europe'; (30) Божидар Димитров: Бежанският поток е от икономически имигранти (14/9/15) 'Bojidar Dimitrov: The refugee stream is of economic immigrants’; (31) Македония обяви кризисно положение по границите заради бежанския поток (20/8/15) 'Macedonia has declared a critical border situation because of the refugee stream.'

- наплив 'influx', e.g. (32) Напливьт на имигранти към Европа продължава (2/9/15) 'The flow of immigrants to Europe continues'; (33) Австрия спря влакове заради наплива на имигранти (10/9/15) 'Austria stopped trains

\footnotetext{
* The use of the Water Metaphor in both Bulgarian and British media is also analysed by Cheshmedzhieva-Stoycheva (2014) and Cheshmedzhieva-Stoycheva (2017b) in this current issue.
} 
because of the influx of immigrants'; (34) Унгария обмисля да ползва армията за справяне с имигрантския наплив (26/8/15) 'Hungary is considering using the army to cope with the immigration influx.'

- цунами 'tsunami', e.g. (35) Имигрантската вълна на Балканите заплашва да се превърне в цунами $(24 / 8 / 15)$ 'The immigrant wave in the Balkans threatens to turn into a tsunami.'; (36) Какво ни заплашва: бежанска вълна или цунами от икономически мигранти? (14/9/15) 'What is it that threatens us: a refugee wave or a tsunami of economic migrants?'

Verbs

As a big body of water a wave has the power to break whatever comes in its way. Big groups of people are also interpreted as dangerous to those who cross their way. Just as waves and flows flood coasts and banks, waves of people flood the countries they pass through, e.g. (37) Вълната от имигранти залива Сърбия и Унгария (25/8/15) 'The wave of immigrants is flooding Serbia and Hungary'; (38) Хиляди мигранти заляха Словения (18/10/15) 'Thousands of migrants overwhelmed Slovenia'. Similarly to sea waves, waves of people are able to expand and enhance in power, e.g. (39) Вълната от имигранти в Европа не спира да се разраства (25/8/15) 'The wave of immigrants in Europe does not stop growing.'

Refugees are associated with military forces which attack and destroy obstacles in their way, e.g. (40) Хиляди имигранти щурмуваха македонската граница (22/8/15) 'Thousands of immigrants stormed the Macedonian border'; (41) Хиляди мигранти пробиха границата между Словения и Австрия (23/10/15) 'Thousands of migrants violated the border between Slovenia and Austria'.

On one occasion refugees are explicitly defined as a threat, e.g. (42) Бежанците представлявали заплаха за туризма в Хърватия (28/9/15) 'Refugees are said to pose a threat to tourism in Croatia.' In this case the journalist, the author of the headline, prefers a specific verb form, the renarrative form, to express his/ her position. Using this particular type of evidentiality* authors emphasize that the source of information is someone else and thus preserve their neutrality.

\footnotetext{
* Apart from being inflected for aspect, tense and modality, Bulgarian verbs are also inflected for evidentiality, that is, the source of the information conveyed by them. There is a distinction between four forms: the unmarked (indicative) forms, which denotes that the speaker was a witness of the event or learned about it as a fact; the inferential, which indicates general non-witness information or one based on inference; the renarrative, which signals that the information was reported to the speaker by someone else; and the dubitative, which is used for reported information if the speaker is not convinced in its truth (Nitsolova 2008: 322-323). Another view is presented by Gerdzhikov (2003: 24-25) who claims that there are two distinctive features involved - subjectivity and renarrativity. The indicative is unmarked for both, the inferential is marked for subjectivity, the renarrative - for renarrativity, and the dubitative is marked for both subjectivity and renarrativity. Kutsarov
} 


\section{Adjectives}

The adjectives used do not follow the WATER metaphor. Rather they belong to a particular semantic field, related to the research topic, and are employed to clarify the information provided. The collocation used most often is нелегални (и)мигранти 'illigal (im)migrants.' '(Im)migrants' also collocates with 'economic'. When used as an adjective '(im)migrant' combines with 'quotas', e.g. (и)мигрантските квоти; 'camp', e.g. незаконен имигрантски лагер 'illegal immigrant camp'; 'crisis', e.g. миграционна криза 'migration crisis'; 'pressure', e.g. имигрантски натиск 'immigrant pressure'; 'wave', e.g. имигрантска вълна 'immigrant wave'. In another collocation 'refugee' as a noun compiles with 'Syrian' - сирийски бежанци. But it can also play the role of an adjective:

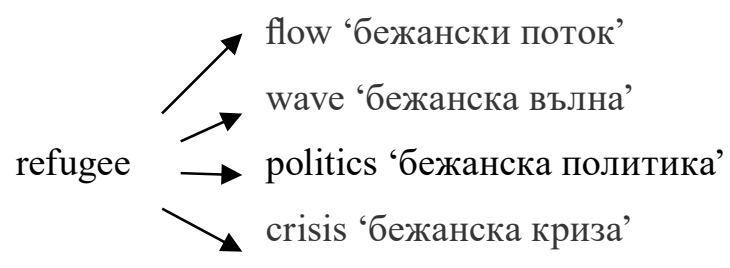

'Refugees' and '(im)migrants' are mostly used interchangeably to refer to the groups of people specified in the samples in the corpus". The same applies to their function as adjectives: антибежански настроения 'anti-refugee moods'; антиимигрантска ограда 'anti-immigrant fence'; антиимигрантски демонстрации 'anti-immigrant demonstrations.'

Numerals

Numerals are commonly used in the news pieces included in the corpus. 62 of the samples in the corpus contain at least one number. They are primarily displayed in digits and stay first in the headline, e.g. (43) 20 нелегални мигранти загинаха при катастрофа в Иран (18/10/15) '20 illegal migrants died in a car accident in Iran', but it is also possible to find them in the middle or at the end

(2007: 294-307), on the other hand, proposes a separate category, which he calls 'type of utterance' (вид на изказването), which only makes a distinction between forms, expressing speaker's own statements (indicative, inferential), and forms that retell statements of another (renarrative, dubitative).

* A 'refugee' (бежанец) refers to people who had escaped their countries because of persecution on racial, social or political grounds (UNHCR). 'Migrants' and 'immigrants' (мигранти, имигранти) choose to leave their countries due to various reasons, such as studying abroad or looking for a job and better living conditions. (Amnesty International). In addition, on the use of references to denote immigrants and/ or refugees and especially on the interchangeable use of the two main terms see Cheshmedzhieva-Stoycheva (2014) as well as Cheshmedzhieva-Stoycheva (2017a: 74) 
of the headline, e.g. respectively (44) Македония пусна 4000 имигранти за ден (23/8/15) 'Macedonia let 4,000 immigrants pass through for a day'; (45) Още един българин арестуван, заради смъртта на 71 имигранти (30/8/15) 'Another Bulgarian arrested in connection with the deaths of 71 immigrants.' When the exact number is unknown journalists use approximations, e.g. (46) Десетки протестиращи блокираха влаковете под Ламанша (3/10/15) 'Dozens of protesters blocked the trains under the Channel'; (47) Стотици мигранти окупираха международната автогара в Истанбул (16/9/15) 'Hundreds of migrants occupied the international bus terminal in Istanbul'; (48) Хърватия е „принудила” Унгария да приеме хиляди мигранти (19/9/15) 'Croatia has "forced" Hungary to accept thousands of migrants.'

Headlines containing numbers imply to their audience a sense of absolute accuracy and exhaustiveness. Their authors report exact data and facts. They create the impression of factual correctness and good knowledge for the details, for journalistic competence and precision in handling the facts. To this group we can also add the headlines that include percentages, e.g. (49) Деница Сачева: В България $42 \%$ от имигрантите са от Сирия (21/9/15) 'Denitsa Sacheva: In Bulgaria $42 \%$ of the immigrants come from Syria.' These are rather results from sociological studies that are quoted.

The corpus does not reveal a wide variety of metonymical expressions. They are frequent but exploit similar mappings:

\begin{tabular}{|l|l|l|l|l|}
\hline \multicolumn{1}{|c|}{ source } & & \multicolumn{1}{c|}{ target } & \multicolumn{1}{c|}{ ехатрle } & \multicolumn{1}{c|}{ gloss } \\
\hline $\begin{array}{l}\text { The } \\
\text { country's } \\
\text { government }\end{array}$ & $\rightarrow$ & $\begin{array}{l}\text { The name of } \\
\text { the country }\end{array}$ & $\begin{array}{l}\text { (50) Хърватия: Не } \\
\text { можем да приемем } \\
\text { повече бежанци } \\
(17 / 9 / 15)\end{array}$ & $\begin{array}{l}\text { Croatia: We cannot } \\
\text { accept more } \\
\text { refugees }\end{array}$ \\
\hline & & $\begin{array}{l}\text { (51) Австрия поиска } \\
\text { спешна среща на } \\
\text { върха на ЕС заради } \\
\text { бежанската криза } \\
(6 / 9 / 15)\end{array}$ & $\begin{array}{l}\text { Austria asked for an } \\
\text { urgent EU meeting } \\
\text { due to the refugee } \\
\text { crisis }\end{array}$ \\
\hline $\begin{array}{l}\text { The people } \\
\text { in the } \\
\text { country }\end{array}$ & $\rightarrow$ & $\begin{array}{l}\text { The name of } \\
\text { the country }\end{array}$ & $\begin{array}{l}\text { (52) Германия } \\
\text { очаква 10 000 } \\
\text { имигранти днес - } \\
\text { рекорд за един ден } \\
(6 / 9 / 15)\end{array}$ & $\begin{array}{l}\text { Germany expects } \\
10,000 \text { immigrants } \\
\text { today - a record for } \\
\text { a day }\end{array}$ \\
\hline
\end{tabular}




\begin{tabular}{|c|c|c|c|c|}
\hline source & & target & example & gloss \\
\hline & & & $\begin{array}{l}\text { (53) } \\
\text { Великобритания } \\
\text { ще отдели до } 12 \\
\text { млрд. лири, за } \\
\text { да подпомогне } \\
\text { сирийските } \\
\text { бежанци (6/9/15) }\end{array}$ & $\begin{array}{l}\text { Britain will allocate } \\
\text { up to } 12 \text { billion } \\
\text { pounds to help } \\
\text { Syrian refugees }\end{array}$ \\
\hline $\begin{array}{l}\text { The } \\
\text { countries in } \\
\text { Europe }\end{array}$ & $\rightarrow$ & Europe & $\begin{array}{l}\text { (54) Митов: } \\
\text { Европа трябва да } \\
\text { започне да връща } \\
\text { имигранти }(4 / 12 / 15)\end{array}$ & $\begin{array}{l}\text { Mitov: Europe must } \\
\text { start sending back } \\
\text { immigrants }\end{array}$ \\
\hline
\end{tabular}

As the corpus shows only proper names play a metonymic function. More specifically, thesearenames of countries and continents (e.g. Europe). We consider this type of metonymy a typical characteristic of the studied headlines.

\section{Multimodality}

The multimodal analysis of the corpus draws on the correspondence between the verbal text in the headlines and the visual representations that accompany them. We have organized the images into several classes: 1) photographs of politicians, 2) photographs of groups of migrants, 3) photographs of children (with a parent or families), 4) photographs of police forces, and 5) photographs with no people. Each of the groups can be further subdivided to display different perspectives on the scene.

1) photographs of politicians

Headlines with citations are accompanied by pictures of the people cited, e.g.

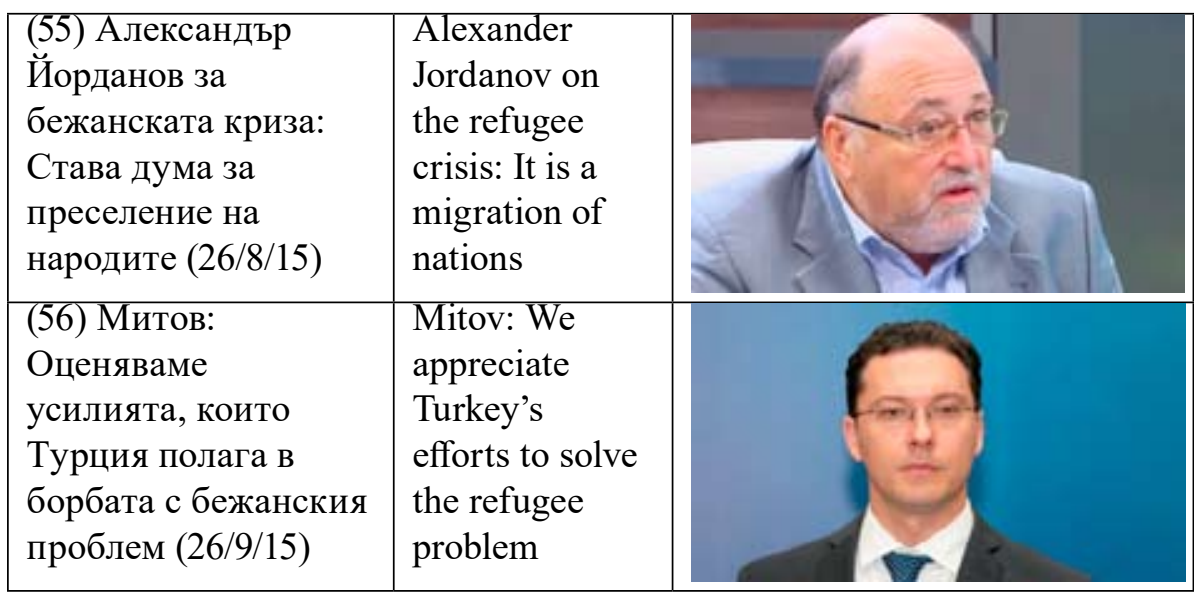


2) photographs of groups of migrants

Headlines containing the WATER metaphor show images of groups of people, e.g.

\begin{tabular}{|l|l|l|l|}
\hline $\begin{array}{l}\text { (57) Хиляди } \\
\text { имигранти } \\
\text { щурмуваха } \\
\text { македонската } \\
\text { граница (22/8/15) }\end{array}$ & $\begin{array}{l}\text { Thousands of } \\
\text { immigrants } \\
\text { attacked the } \\
\text { Macedonian border }\end{array}$ & $\begin{array}{l}\text { Thousands } \\
\text { of migrants } \\
\text { overwhelmed } \\
\text { Slovenia }\end{array}$ & $\begin{array}{l}\text { (58) Хиляди } \\
\text { мигранти } \\
\text { заляха Словения } \\
(18 / 10 / 15)\end{array}$ \\
\hline
\end{tabular}

3) photographs of children (with a parent or families)

Headlines mentioning certain social practices, for instance, helping the migrants on their way, providing shelter and food are presented together with photographs of children in the foreground, e.g.

\begin{tabular}{|l|l|l|}
\hline $\begin{array}{l}\text { (59) Македония обяви } \\
\text { кризисно положение } \\
\text { по границите заради } \\
\text { бежанския поток } \\
(20 / 8 / 15)\end{array}$ & $\begin{array}{l}\text { Macedonia has } \\
\text { declared a critical } \\
\text { border situation } \\
\text { because of the } \\
\text { refugee stream }\end{array}$ \\
\hline $\begin{array}{l}\text { (60) В Чехия } \\
\text { пристигнаха } \\
\text { първите 16 сирийски } \\
\text { бежанци, получили } \\
\text { убежище (13/10/15) }\end{array}$ & $\begin{array}{l}\text { The first 16 Syrian } \\
\text { refugees, who } \\
\text { have been granted } \\
\text { asylum, arrived } \\
\text { in the Czech } \\
\text { Republic }\end{array}$ \\
\hline
\end{tabular}


4) photographs of police forces

When deliberate actions on the part of the police forces are explicitly mentioned or implied, there is an image to round out the impression, e.g.

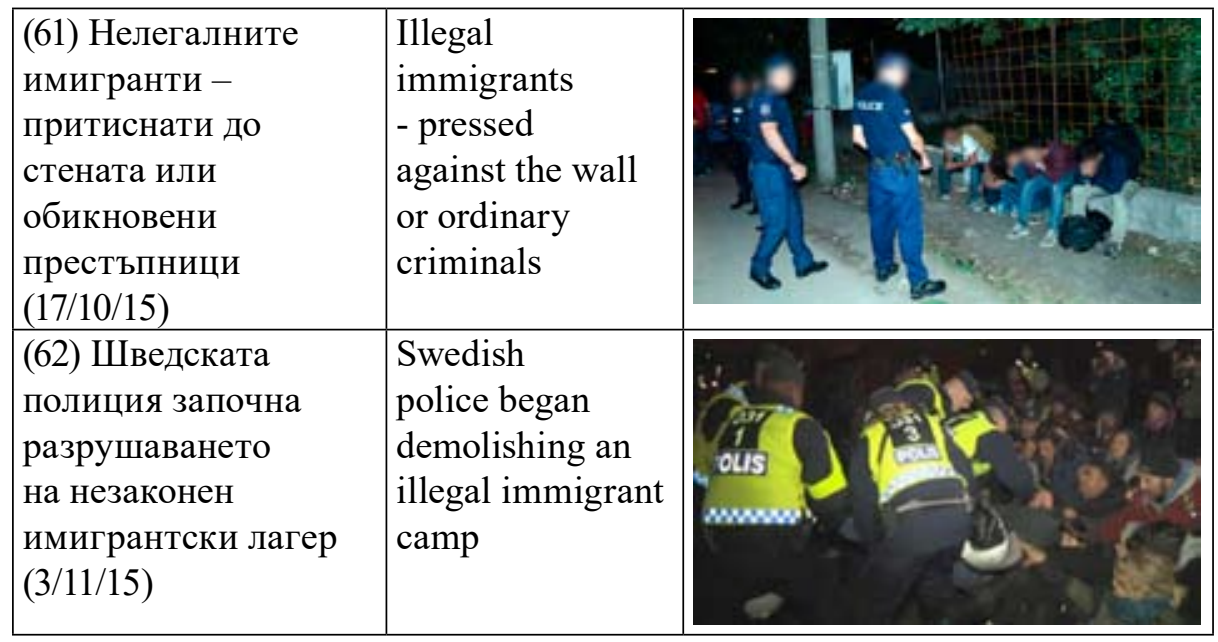

5) photographs with no people

These images focus on metaphorical mappings on the part of the reader. Barbed wire is associated with an impassable obstacle similar to a border wall mentioned in the headline. The building of the Reichstag is a symbol of Germany which corresponds to the toponym specified in the title.

\begin{tabular}{|l|l|}
\hline $\begin{array}{l}\text { (63) Унгария: Само } \\
\text { стената може да ни } \\
\text { спаси от бежанците } \\
(18 / 8 / 15)\end{array}$ & $\begin{array}{l}\text { Hungary: Only } \\
\text { the wall can } \\
\text { save us from the } \\
\text { refugees }\end{array}$ \\
\hline $\begin{array}{l}\text { (64) Германия чака } \\
750000 \text { бежанци до } \\
\text { края на годината } \\
(18 / 8 / 15)\end{array}$ & $\begin{array}{l}\text { Germany is } \\
\text { waiting for } \\
750,000 \text { refugees } \\
\text { by the end of the } \\
\text { year }\end{array}$ \\
\hline
\end{tabular}

Photographs devoid of people are used as a device to draw the reader's attention to particular objects, metaphors in themselves.

Both the headlines and the accompanying images reveal two opposing dispositions to the migrants. On the one hand, they are vulnerable people who 
have suffered immensely leaving their homes and travelling all the way to the Promised Land - Europe. Many of them have lost their property, friends and relatives on the way, and some of them their lives. These are people who need help and compassion on the part of European people and their governments. On the other hand, migrants are represented as a powerful threat to the receiving states' standard of living, social security and welfare system. The EU countries could not provide suitable infrastructure to handle the thousands of people arriving. Local people help the passing migrants but at the same time they feel afraid for their way of living if the refugees are given asylum and stay in their countries.

\section{Conclusion}

A challenge we face when studying media texts is how to come to valid conclusions as critical discourse analysis is very time-consuming and poses problems when we undertake a detailed analysis of a large number of news articles. We sought a way which would give us the opportunity to overview an extensive corpus. Therefore, we chose to study the headlines, a strategy offering a number of distinct advantages. A corpus of headlines facilitates quantitative analysis, for instance, a study of the number of headlines on a particular issue can show the changing prominence of a topic over time.

We claim that the positive representations of the migrants in our corpus relates to Bulgarian official foreign politics and the positive image of Bulgarian politicians who appear as illustrative models of Bulgarian people (e.g., as humane, compassionate, responsible, willing to help the migrants) in contrast to the negative image and decisions of other countries (e.g., Hungary for erecting a wall, Macedonia and Serbia for not collaborating in logistics, etc.).

To increase the impact of headlines journalists rely on certain linguistic features of the titles to make them particularly memorable and effective: impact is deliberately sought through the metaphors, metonymies and numbers as our analysis showed. The use of citations, as well as the specific Bulgarian renarrative form prove to be effective when the author of the headline would like to set a distance between himself/herself and what the headline says.

We also suggest the following features as typical of news headlines in quality press of which bTV news is a representative:

a) the predominance of whole sentences to verbless clauses;

b) merging two sentences into one to achieve headline's brevity;

c) the domination of nouns to verbs and adjectives;

d) lack of direct speech punctuation (e.g. quotation marks), etc. 
This study has helped us to identify certain recurring linguistic features of the headlines in our corpus. We have also found two opposing images of the represented migrants: one positive - seeing them as a vulnerable group that deserves help and compassion; and one negative - viewing them as a threat to the EU social order.

Our aim here, however, is not to provide an exhaustive account of the representation of migration in online news. Our future research is going to identify those linguistic features of headlines which are of particular relevance to the study of national representations, i.e. representations of one's own nation, people and country, and the representations of other nations, along with the interrelation of both categories of representation, the similarities and contrasts that can be created, and the role played by representations of the other in defining one's own nationality and identity.

\section{References:}

Amnesty International: Amnesty International <https:/www.amnesty.org/en/what-wedo/refugees-asylum-seekers-and-migrants/ $>$ [Accessed 30 Sept. 2017].

Cheshmedzhieva-Stoycheva 2014: Cheshmedzhieva-Stoycheva D. A New Public Scare: Syrian Refugees in Some Bulgarian and British Newspapers. - In: Dobrev D., H. Trendafilov (eds.). Studia Hungaro-Bulgarica. Vol. 3. Sumen-Szeged. 123-140.

Cheshmedzhieva-Stoycheva 2017a: Cheshmedzhieva-Stoycheva D. The Image of the Refugee: Real and Imagined. (Based on Examples from the Bulgarian and the British Media). - Science and Education a New Dimension. Humanities and Social Sciences. V (22), I. 73-76.

Cheshmedzhieva-Stoycheva 2017b: Cheshmedzhieva-Stoycheva D. Stereotypes and Prejudices at The Border: An Attempt at Raising Intercultural Awareness through Examples from the Bulgarian and the British Media. - In: Todorova et al. (eds.). Crossing Borders and Bridging Gaps in English Language Teaching and Research. Series in Linguistics, Culture and FLT, issue 2. Asenevtsi, 2017. 184-197.

Gerdzhikov 2003 [1984]: Gerdzhikov G. Preizkazvaneto na glagolnoto deystvie v Bulgarskiya ezik (in Bulgarian), Sofia: St. Kliment Ohridksi University.

Isani 2011: Isani Sh. Of Headlines \& Headlinese: Towards Distinctive Linguistic and Pragmatic Genericity. <https://asp.revues.org/2523 > [Accessed 5 June 2017]

Jewitt, Bezemer, O’Halloran 2016: Jewitt C., Bezemer J., K. O’Halloran. Introducing Multimodality. Abingdon and New York: Routledge.

Kress, van Leeuwen 2006 [1996]: Kress G, Th. van Leeuwen. Reading Images, The Grammar of Visual Design. London and New York: Routledge.

Kutsarov 2007: Kutsarov G. Teoretichna gramatika na Bulgarskiya ezik. Morfologia (in Bulgarian), Plovdiv: Paisiy Hilendarski.

LSA: LSA (Linguistic Society of America) https://www.linguisticsociety.org/resource/ discourse-analysis-what-speakers-do-conversation [Accessed 20 Feb. 2016] 
Matthews, Brown 2012: Matthews J., A. R. Brown. Negatively Shaping the Asylum Agenda? The Representational Strategy and Impact of a Tabloid News Campaign. Journalism Criticism, Theory and Practice, Vol 13, No 6, 802-817. Sage Publications.

Nikolova 2003: Nikolova A. Informativnost na vestnikarskoto zaglavie. Vlastta na mediite. Studii $i$ statii. Shumen.

Nitsolova 2008: Nitsolova R. Bulgarska gramatika. Morfologia (in Bulgarian), Sofia: St. Kliment Ohridksi University,

Pernishka 1999: Pernishka E. Za "groznoto" v nashiya ezik i v ezika na mediite. Mediite i ezikat. Izdatelstvo "Eto", Sofia.

REACH: REACH (Informing more effective humanitarian action) $<$ http://www.reachinitiative.org/reach/about-reach> [Accessed 20 Feb. 2017]

Salih Abu Joloud 2015: Salih Abu Joloud M. Punctuating Headlines (Online Headlines and the uses of punctuation). $<$ http://alustathiq.com/LionImages/News/21-2015.pdf $>$ [Accessed 07 June 2017]

The Guardian 2016: The Guardian. <https:/www.theguardian.com/world/2016/aug/30/ tens-of-thousands-migrate-through-balkans-since-route-declared-shut $>$ [Accessed 20 Feb. 2017]

UNHCR: UNHCR (The UN Refugee Agency) < http://www.unrefugees.org/what-is-arefugee/ $>$ [Accessed 20 Feb. 2017]

Van Leeuwen 2008: Van Leeuwen T. Discourse and Practice: New Tools for Critical Discourse Analysis. New York: Oxford University Press.

Zambova 2000. Zambova A. Manipulativni ezikovi strategii v pechata. Sofia: Sema RSh. 